\title{
THE AMERICAN REVOLUTION - AN INTERPRETATION
}

\section{Prof. M. SWEARINGEN}

I would liketo begin by saying that I am happy to be among you, and I am proud to bring the greetings of one revolutionary people to another.

The word "revolutionary", however, should be handled with care, because it carries such diverse emotional overtones. We are all too painfully conscious of the fact that certain revolutions in our own time have set the teeth of the western world on edge. I can remember that most of the European and American people gave a kind of guarded approval to the Kerensky revolution in 1917 , but I can recall little enthusiasm for the Lenin revolution that took place later in the same year - either at the time it occurred or at any time since. Similarly, most of us liked the Sun-Yat Sen revolution, but the Mao Tse Tung revolution has not noticeably increased our happiness. Western people quite naturally applauded the Atatürk revolution, but the Mussolini and Hitler revolutions caused us considerable trouble.

The distasteful character of the revolutions in Russia, Italy and Germany has brought the word revolution, and its adjective revolutionary, into disrepute in the United States, but in Mexico these are still good words instead of bad words. When I was on a visit there in I939 I thought it quite illuminating that an organization or project that needed popular support usually added the adjective "revolutionario" to its title. But if, at that time, anyone in the United States had tried to promote, let us say, a "Revolutionary Study Club" or a "Union for Revolutionary Social Action" he would have found himself subject to instant pressures or even to official investigation. That this should be true in a nation that builds monuments to George Washington and Thomas Jefferson is interesting indeed.

The temptation, of course, is to argue that this important psychological response to the word "revolution" simply reflects a form 
of petty nationalism, that people like their own kind of revolutions but do not like other kinds. This could be supported by the fact that Americans saw some likeness between their own revolution and the revolutions of Sun-Yat Sen and Atatürk, and therefore applauded, while they saw only differences in the Lenin and Mao revolutions. But this would be a superficial and trivial explanation, because revolutions clearly reflect certain values that people hold important, and values are not just a matter of national taste, but are a product of social philosophy, history, and religion.

The American sensitivity with respect to revolutionary thought today derives from the suspicion of the American people that they have already had, long ago, the only kind of revolution that could preserve the values they cherish, and that any new revolution would only destroy these values. There are two reasons for this suspicion. One is that the success of Russia in keeping her experiment alive for $3^{8}$ years has made such a deep impression that Americans have largely lost sight of other kinds of revolution, and they tend to equate any current revolutionary idea or movement with communism. The other reason is that the Americans in creating the United States I68 years ago, managed to institutionalize revolution-to write it into their fundamental framework - in such a way that they cannot believe that a revolution of violence is any longer necessary to bring about the social, economic or political changes which might be needed in the United States. Their nation has been "revolutionized" several times since 1787 , and with the exception of the revolution that accurred concurrently with the Civil War, all these fundamental changes have taken place not only without violence but even in some cases without widespread popular realization that anything at all had happened

It is this last point that has persuaded me to devote my first lecture in Ankara to an appraisal of what my forefathers were trying to do - and what they did-in the critical years when they were creating the United States. It was their success in wrapping up all American revolutionary impulses in one big package that makes their experience unique.

It is appropriate to begin by pointing out that the American Revolution was the first great social upheaval of the liberal era. 
The Glorious Revolution of $1688-1689$ in England certainly had priority in time, and it clearly was a sort of capstone to the long, hard work by which the English evolved their free constitutional government, but it belongs in another age and another setting. The English Revolution occurred before the liberal philosophy had been worked out; it was more a cause of that philosophy than an effect of it. The Bill of Rights resulting from it expressed no political theory because the leaders of the revolution were not working from the premises of a systematic political philosophy. They were intent only on forcing the monarch to agree that he would not in the future do those things which the English did not like, and which previous kings had done. The principle of parliamentary supremacy was firmly set but nowhere stated. It was following this revolution that John Locke wrote a philosophy ex post facto - explaining and justifying it. This philosophy of Locke led directly into the liberalism which was elaborated as a system in the 18 th century. The Americans were the first to have a revolution based on this, whereas their English kin had had their revolution in a kind of philosophical void.

The Americans, then, were the people who first put the liberal dogma to the test of revolution, and their reasons for doing so are highly instructive. Basically, these reasons are only two in number. The first is that from the outset the Americans had been a people of revolutionary temper; just the simple fact that they were in America instead of in England constituted by itself a sort of revolution, and the sum total of their experience in America confirmed it. The second is that they were too well off to run the risk of not having a revolution; they had the unique historical experience of revolting not to correct an intolerable condition but to maintain a status quo in which they were better off than most of the people in the Western world at that time.

These two reasons will be clearer if they are supported by some detail. The revolutionary temper of the American people, for example, can be at least in part assumed from the fact that the first large migration from England to America took place at a time when the English themselves were in a revolutionary mood. It is well to remember that when Virginia was settled the English Renaissance had not yet run its course; Elizabeth was only fours years dead, Wal- 
ter Raleigh and Francis Drake were still alive, Shakespeare was still writing plays and Francis Bacon was about to write his best works. It would be ridiculous to conclude that all the common Englishmen who fled to America were good Renaissance types in open revolt against medievalism, but we know that when a ferment starts among the intellectuals of a nation some of its spirit seeps through all levels of the population, and it is clear enough from the record itself that the people who came to America were modern men. At least they had imagination and a lusty courage, or else they would have stayed at home in the hum-drum hope that things would get better after a while.

But we can be more concrete than this. An economic revolution was in progress in England, as well as a political and religious revolution. The economic revolution was a major cause of the migration; so many English had become misfits in the new economy that they required a personal revolution of their own to solve their problem, and their personal revolution took the form of removal to America. Very much the same was true of the religious revolution, only in this case the Englishmen who came because of religious reasons were, in the main, coming because the revolution had lagged; they wished to be Puritans without waiting for the approval of the English government. Closely related to all this was the urge to be free, and surely this is also central in the struggle between king and parliament which lasted almost all the century.

The revolutionary temper that the English brought with them was confirmed by their American experience in the sense that they ceased after a while to be Englishmen. By the middle of the r8th century something called an "American" had appeared- a new type of man - homo americanus. He was not an English colonist any longer, but something sui generis, and he had built a society which proved it. In this society he was the freest man that could be found anywhere in the world of his time. He not only could go to the polls and vote, but he also did not have to pay any tax that had not been levied by his own elected representatives; he had a wider lattitude of religious freedom than any other human; he had a better economic opportunity than any man in Europe; when he committed an offense he was tried before a jury of his neighbors, and if he was punished, 
it was by the law that had been written in an assembly elected from among the people themselves.

This leads to the second reason - that the Americans were too well off to run the risk of not having a revolution. I think it can be said that the revolution in America came before the Revolutionary War; the fighting was not to make a revolution but to save one that had already happened.

The point here is that in many ways, none of them intentional, the English government had been accessory before the fact in bringing about this situation. It began very early, when in I6r9 the Virginians were permitted to have their own legislature. It continued in such ways as permitting the settlers of Massachusetts to bring their charter with them, granting free charters to Rhode Island and Connecticut by which the residents had complete control of their government, permitting American merchants to violate the Navigation Acts almost at will, and, in the r 8 th century, generally neglecting and ignoring all the colonies to such a degree that Americans could nearly forget that they were a part of the British Empire. When the year 1763 began there were no really binding ties between the colonies and the mother country; the vague allegiance to the king, the royal governors who were nearly impotent, the old trade laws which were systematically violated; these were about the sum of it. Americans were almost as free as people ever get to be.

In 1763 , however, a change began to occur in their situation. This resulted from the dilemma confronting the English government. England had emerged from the Seven year War victorious; she had finally achieved her dream of imperial supremacy by winning both India and Canada; but she also had to carry the burden of a crushing war debt. In these circumstances the English politicians saw quite clearly that the old casual ways of administering the empire would not do. The whole of England's vast and scattered colonial holdings would have to be coordinated, closely administered, and forced to pay their own way.

England thereupon embarked on a new colonial policy, the essence of which was the reassertion of her undoubtedly constitutional authority over her offspring. The necessity for this was so clear that even Americans might have acknowledged it and cooperated, 
had it not been that the English government at that time was peculiarly unfit to deal with a problem of such magnitude. The young King George III, who came to the throne in 1760 , had made up his mind that he would make an all-out effort to recover the personal powers of the king which had been largely lost by default in the reigns of his grandfather and great-grand father. This ambition of the king got English politics so hopelessly embroiled that government became dangerously ineffective. Most of the first rate political minds in England were either driven out of office, or retired from it in disgust. Thus a vitally important change in imperial policy had to be directed by statesmen of second and third rank. It should be added here that George III himself suffered not only from stupidity but also intermittent spells of insanity.

The upshot was that the new policy, as it unfolded during the next ten years, turned out to be a series of acts which were either silly or impossible to enforce - and in some cases both. This bungling was a free gift to certain talented radicals in the American colonies. They began almost at once to shout "tyranny", to create revolutionary organizations, to develop effective methods of propaganda and agitation, and to straighten out in their own minds a philosophy -a program - for revolution. On the Fourth of July in the year 1776 this philosophy was agreed upon, and was set down in the second paragraph of the Declaration of Independence.

The revolutionary philosophy so compactly stated in this famous paragraph has a familiar ring to us today, but it is more important for us to understand that it also had a familiar ring in the ears of educated Europeans and Americans at the time it was written, because it was borroved from the intellectual storehouse of the Age of Reason. Mostly it is a condensation of the political philosophy of John Locke. It says that men are created equal and have natural rights; that men make their own governments for the purpose of preserving these rights; and that when governments destroy rather than preserve these rights, men have the right to overthrow such governments by revolution, and start all over again. Only in one important respect did this depart from Locke. In ticking off the natural rights of man Locke would probably have said "life, liberty and property"; the Declaration says "life, liberty and the pursuit 
of happiness." Here was the new world speaking, telling the old world that the sights had been raised and that there was now a new target more inclusive than wealth; the ultimate aim in America was to be human happiness. Happily no definition was attempted.

I suppose it is important to remember that Thomas Jefferson wrote this, but I cannot help feeling that its wide acceptance among thinking people at that time is what really counts. John Adams was on the committe with Jefferson, and he accepted it. The members of the Continental Congress voted on it and passed it. Beyond any reasonable doubt it was the agreed philosophy of the revolution, and it was the philosophy of freedom. It meant that governments were the servants, not the masters, of men, and that governments must stand or fall by the test of whether they preserved or destroyed the natural rights of men. And it was not written to inaugurate this principle, but to protect it in the form in which it already existed throughout the colonies.

The Revolutionary War came to an end in 1783 , and the colonies were free - much too free, as it turned out. The war had left the usual social dislocations, the most grievous of which was economic $\mathrm{d}$ isorder. Farmers were in despair because of falling prices that left them no way to pay off mortgages; merchaats were no longer welcome in British ports and to had to seek new trade; soldiers were unpaid and adrift; the states were in debt; the Continental currency was worthless; there was no national treasury. To complicate this picture, the thirteen separate states thought mainly of their separateness; when they broke their ties with England they assumed that each state had broken its own indiwudual tie and that no state had any legal or costitutional bond with another. This led to violent jealousies, border disputes, tariff disputes, and disputes over rivers. Had there been some sort of effective common government the solution to these problems might have been found, but the only government with any pretense of authority over all the states was that set up by the Articles, of Confederation.

This government under the Articles had been reluctantly agreed to by the states in the last year of the war, and the only reason that it was able to win even reluctant acceptance was that it did not really have any authority. It was purely a legislative government, 
without an executive, without a treasury, without a system of courts, without power to levy taxes. The only thing that can be said in its favor is that it was the only kind of government the American people would have tolerated at that time. They had been fighting a war for freedom, they had expressed their passion for freedom in the Declaration, and they would have considered it a ludicrous paradox had anyone suggested that-during a war for freedom from the strong government threatened by England - they voluntarily accept a strong government on this side of the Atlantic. They acknowledged the necessity of state and local governments, to which they were loyal - but a remote government, particularly a powerful one, that was something else again.

Freedom, then, was in the ascendancy after the Revolution-a costly and dangerous freedom, a parochial freedom indifferent to the realities of life in an organized society. This point was clear enough to many of the ablest men in America, and they soon were hard at work to see what they could do. George Washington, Alexander Hamilton, James Madison and others like them knew that men could not live the good life without freedom; but they also knew what most Americans were loath to admit, that men cannot live the good life without order. They took on the task of solving the dilemma that is inherent in any society of free men: how can freedom be preserved without order, and how much order can be maintained without threat to freedom.

The result of this thinking was the Constitution of the United States. This was written by a small group of men in five weeks working time during the summer of 1787 . It has long been the habit of scholars commenting on such an achievement to use a tone of hushed awe. It is commonplace to point out that the United States, though one of the youngest nations, has the oldest constitution in existence. That this could have been contrived by a few dozen men in less than forty days suggests the active intervention of Providence. William. Ewart Gladstone has been repeatedly quoted as having said that the Contitution of the United States was the greatest work ever struck off by the mind and hand of man in a given time. I have taken pains not to put quotation marks around this statement, however, because I must confess that I have never found it among $\mathrm{Mr}$. Gladstone's voluminous utterances. 
It seems to me, though, that commentators on the American Constitution have been awe-struck mainly because they have overlooked something. I believe the Constitution could be written so quickly and with such relative ease because most of it was already in existence in the thought and experience of the American people. Governments with elected excutives were nothing new to them; Rhode Island and Connecticut, for example, had been electing their governors for nearly I50 years. Representive legislatures with two houses, at least one house elected by the people, were the rule rather than the exception during most of the colonial period. The idea that people might create a frame of government for themselves was as old as the Mayflower Compact and had been confirmed by every state after its separation from Britain in the beginning of the Revolution. The idea that government is limited in its power and can be restrained by the people was stated by Locke before the end of the I 7 th century and had passed into the general pattern of 18 th century political liberalism not only in America but also in the western parts of Europe. In the generation since the publication of Montesquieu's Esprit des lois the belief that powers of government should be divided among three separate branches had become part of the liberal dogma and had been put into practice in some of the states after their separation from England. The whole political process of franchise and voting had ancient English origins; so did those parts of the Constitution that reflected Blackstone's writings on the common law; so did th e feeling that only a lower house in the legislature could properly inaugurate bills having to do with taxation and appropriation. Indeed so much of the Constitution either eixted already in American thought, or had even been common in American experience, that we are hard put to it to find out what the founding fathers did that was new.

New things can be found, however, and one of them is probably the most important single feature of the Constitution. This is the solution of the problem of federalism. The history of Europe, from as far back as the Age of Kings in Greece, gives ample evidence that western people understood monarchy in various forms and that they could also successfully operate unitary republics. But up to 1787 the history of federalism is overwhelmingly a history of failure, despite some promising, small-scale efforts in such places as Switzer- 
land and Holland. A federation is made up of pre-existing units which have autonomous backgrounds; integrating such units under a common goyernment raises the problem of final authority, or sovereignty. The component states tend to guard jealously their traditional autonomy while the central government will grasp at all the power it can lay its hands on. Faced by this dilemma, federations have tended to be loose leagues rather than politically effective states, because the component states, historically, have normally reserved for themselves enough freedom of action to neutralize the central power.

The American political leaders at Philadelphia in 1787 very cleverly solved this dilemma by refusing to meet it. They knew that if they made the national government supreme the Constitution would not be ratified, and that if they left the states sovereign they would not improve over the Articles of Confederation. They therefore deliberately omitted to make any government supreme - either local or central - thereby apparently leaving the question of final authority open, so that it became customary to regard the Constitution as having established an anomalous arrangement by which the central and local governments had equal or joint sovereignty. This evaded the touchy question as to whether either government (central or local) could impose its authority on the other; it particularly bypassed the exceedingly dangerous problem of how to make the will of the central government effective on the states.

This evasion was, however, illusory if not actually deceptive, because in Article VI there appeared the following rather innocentlooking provision:

This Constitution, and the Laws of the United States which shall be made in Pursuance thereof; and all Treaties made, or which shall be made, under the Authority of the United States, shall be the supreme Law of the Land; and the Judges in every State shall be bound thereby, any Thing in the Constitution or Laws of any State to the Contrary notwithstanding.

The founding fathers did not make any government supreme or sovereign over any other, but they didn't have to, because they pro- 
vided that federal law should be supreme over all other law. Thus it was not necessary to deal with the dilemma of how to impose the will of the federal government on the states, because the will of the federal government could be imposed directly on individuals - the people themselves - without even a polite nod in the direction of a state government. Many have argued that even this most ingenious device was not enough, in view of the fact that the American people later made their own positive decision on the location of sovereingty by resort to arms in the Civil War. This approach seems to suggest both that the Civil War might not have occurred had the problem of sovereignty been settled in the Constitution, and that the people thought the exact residence of sovereignty was worth fighting over. But I believe the Civil War was fought about something else, and the decision with respect to sovereingty was corollary or derivative, and I believe that no union would have been possible in I 787 anyhow had the Contitution attempted to solve the dilemma in any way except by indirection.

The solution of the dilemma of sovereignty in the Constitution involves one more step beyond the evasion and indirection which have just been described. This is the astute division of powers between the central and state governments, and here the authors must be frankly credited with great wisdom. They saw that certain powers could be safely trusted only to the central government, that others must be allowed to both central and state governments, and that still others would best be the province of the states alone. The temptation to illustrate this by copious examples is strong indeed, but there is time only to point out that the coinage of money, and foreign affairs, are clearly federal, that taxation and the establishment of courts were essential to both central and state governments, and that the type of police regulations that so directly touched the lives of the people were by their nature local. Few features of the Constitution have aroused so much admiration as the insight with which powers were allocated within this classification.

It has been the practice of American historians to say that this Constitution worked so well, and has endured so long, because it was severely practical. In those portions of it dealing with immediate issues on which the Americans were sharply divided - such as 
slavery, and import and export duties - no principle was applied except the principle of getting on together, the principle of compromise. There is not a clause in the whole document commiting the United States by explicit statement to any theory or philosophy of government. The Preamble-which is where theory belonged if there was to be any-reads as follows:

We the people of the United States, in Order to form a more perfect Union, establish Justice, insure domestic Tranquility, provide for the common defence, promote the general Welfare, and secure the Blessings of Liberty to ourselves and our Posterity, do ordain and establish this Consitution for the United States of America.

These are work-a-day matters. Perhaps these phrases commit the Americans rather vaguely to the "Blessings of Liberty", but they do not bind the Americans to any specific form of society under some such name as democracy, liberalism, or capitalism.

It has also been the practice of a few American historians to say that in 1787 the American Revolution was turned over to its enemies. The reason for this is that the Constitution which was written in that year concentrated on order to the neglect of liberty; its authors, in this view, very nearly forgot the Declaration of Independence. It must be remembered in support of this that the Costitution in its first form had no Bill of Rights, which had to be provided later by amendment.

Both these views are subject to substantial qualification. Although it is true that no explicit wording in the Constitution commits the United States to any prescribed theory or philosophy of government, it is none the less true that the specific provisions do by themselves constitute a remarkably clear statement of a philosophy, the philosophy of I 8 th century liberalism. The Constitution says by clear inference, in first one place and then another, that political power depends on the consent of the governed, that people have rights, that the government must obey the law and that the people can require it to. After all, the Constitution was not written in an intellectual vacuum; it was written in a specific time and place characterized by a definable intellectual climate; part of this climate was the political liberalism which stemmed from Locke, which had 
developed rapidly in France, and which had been current among American intellectual leaders from its inception. Further, the Constitution not only says, by inference, that the United States is a liberal republic, but in the same way says also that it is a capitalistic republic; this too is plucked out of the air of the I8th century. So whether the Preamble says so or not the nation was created on a foundation of political liberalism and capitalism.

This gives us the material for dealing with the second view that the Revolution fell into its enemies' hands in 1787 . What this view ignores is that liberalism in the 18 th century did not normally mean democracy. It also ignores the fact that liberalism was also in large measure a doctrine of the rising middle classes - the business men brought into existence by the growth of capitalism. The radicals of the American Revolution, such as Thomas Jefferson and Thomas Paine, were psychologically and emotionally prepared to push the inferences of liberalism all the way to democracy, but this did not necessarily mean that they were more liberal (or better liberals) than their associates who were content to set up a government of limited powers under the firm control of capitalist business men. These latter were also revolutionaries, and in the context of their own time they were in some ways more radical than Jefferson. In 1787 they too were the men of the future. And it was they who, in dominating the Constitutional Convention, corrected the excesses of liberty and swung the pendulum.towards order.

In 1789 the government of the United States went into operation under the Constitution, with George Washington as president, Thomas Jefferson as Secretary of State, and Alexander Hamilton as Secretary of the Treasury, and in the space of a half-dozen years the potentialities of the Constitution began to be evident. Hamliton dominated Washington's administration, and as the principal spokesman for American business men he sought to use every ounce of power which the government could claim under the Constitution towards the end of making the Unites States a kind of Utopia for capitalists. In his construction of a program for the administraion he took one step of the highest theoretical importance-he ejected, out of hand, the-new doctrine of economic liberalism which ad arisen from the Physiocrats and Adam Smith. Far from sepaating business and government under the classic banner of free Tarih Arastırmalari F. 5 
enterprise, he went to extraordinary lengths to make government and business dependent on each other, and he established in America the practice of government "meddling" in economic matters in the name of "public welfare".

To Hamilton public welfare meant, of course, friendly government help in the development of a large, vital, prosperous business community. I suppose it did not occur to him that in later years the idea of government meddling in the economy, for the sake of public welfare, could be given another meaning, and that the operation of a large socialist experiment like the Tennesse Valley Authority could be held constitutional by the courts and could arouse such fervent popular support. No better illustration can be found of how important it is that the Constitution did not commit the United States by any specific statement of theory to any specific social doctrine. However capitalist the Constitution is in its actual provisions, it contains no effective barrier to socialism if the people of the United States shall ever wish to have a socialist society.

The Americans, therefore do not need any more revolutions, and do not necd a new Constitution, in order to have some new form of society; they have made their one real bloody revolution do the whole job for them. But this is not necessarily all to the good. We learned in severarl wars that the Constitution will per. mit the personal dictatorship of a powerful president; we have seen in the history of several states - notably Lousiana and Georgia - that republican constitutions can be perverted to the ends of authoritarianism even in times of peace. It is still true, then, that the protection of American freedom depends upon American love of freedom rather than upon the Constitution, and if another revolution comes in America it will come as the first one did for the preservation rather than the achievement of freedom.

I hope it will have been noticed that in this highly condensed version of the American Revolution and the foundation of the Unit ed States I have drawn no parallels or contrasts between the revolutionary experiences of the American and Turkish people. But these parallels and contrasts do exist. Such of them as you have found in this paper I offer to you as a free gift, but without any comment on elaboration of my own. 
I close now with a pair of monumental observations. Many years after the American Revolution the people of the United States built a memorial to George Washington. It was in the form of an obelisk, tremendously tall and erect. It has a fully finished look; it comes to a neat point at the top. Maybe this impressive shaft is intended as a kind of pointer -upwards; maybe even it is threatening to puncture the very floor of heaven and let all Americans in through the hole,- perfect symbol of the pursuit of happiness.

In Ankara, at least a dozen times a day, I go out on the little balcony outside my window to enjoy the splendid beauty of the Atatürk Mausoleum. It does not have the utterly finished look of the Washington Monument; sometimes I feel it looks more as if it had been built to serve as the foundation for something else. This could be a perfect symbol too, provided we think of the open sky above it not as a place to pile more stone but as a sacred space to be filled by the hopes and dreams of the Turkish people. 